\title{
Production of Antitumor Agents from Novel Marine Actinomycetes Isolated from Alexandria, Egypt
}

\section{Manal M. El-Naggar ${ }^{1 *}$, Samy A. El-Assar ${ }^{2}$ and Abir Mohamed Ali Shata ${ }^{1}$}

${ }^{1}$ Microbiology Lab, Environmental Division, NIOF, Alexandria, Egypt

${ }^{2}$ Department of Botany and Microbiology, Faculty of Science, Alexandria University, Alex, Egypt

*Corresponding author: Manal M. El-Naggar, Microbiology Lab, Environmental Division, NIOF, Alexandria, Egypt, Tel: 202-03- 4807140; E-mail: mmelnaggar@yahoo.com

Rec date: Mar 27, 2015; Acc date: Mar 30, 2015; Pub date: Mar 31, 2015

Copyright: (C) 2015 El-Naggar M, et al. This is an open-access article distributed under the terms of the Creative Commons Attribution License, which permits unrestricted use, distribution, and reproduction in any medium, provided the original author and source are credited.

\section{Editorial}

The need for novel anticancer agents is a must because of; the development of multidrug resistance in patients, the Long-term treatment with cancer drugs is also associated with severe side effects, the cytotoxic drugs have the potential to be very harmful to the body unless they are very specific to cancer cells. So, new drugs that will be more selective for cancer cells will be more safe and healthy for human. The obtained active marine natural products of novel actinomycetes were tested through three replicates (R) using colon cell line in comparison to the common used chemotherapeutic agent (5flurouracil) (Figure 1)

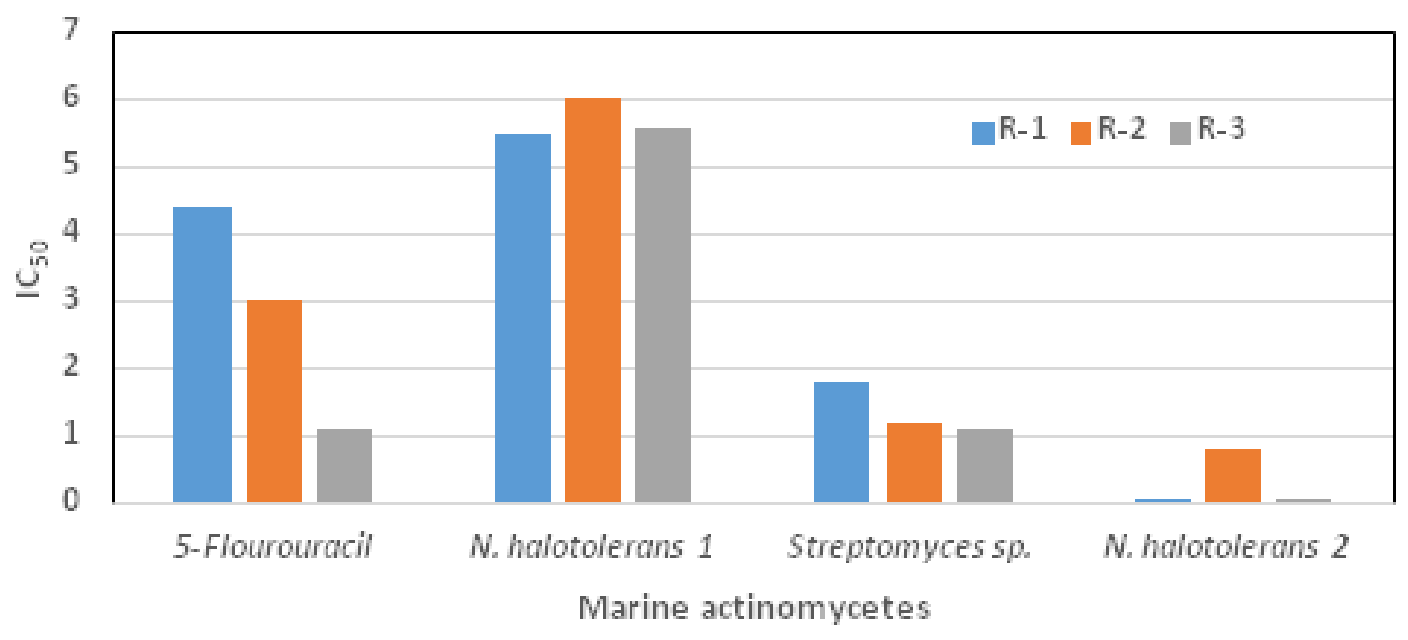

Figure 1: The activity of different marine actinomycetes against colon cell line. 